\title{
Enumeration of Culturable Endophytic Bacterial Population of Different Lycopersicum esculentum L. Varieties
}

\author{
Monika Singh, Prem Pratap Singh, Arun K. Patel, P.K. Singh and K.D. Pandey* \\ Centre of Advanced study in Botany, Institute of Science, Banaras Hindu University, \\ Varanasi-221005, India \\ *Corresponding author
}

\section{A B S T R A C T}

Tomato (Lycopersicum esculentum L.), is a most common vegetable crop worldwide and

\section{Keywords}

Lycopersicum esculentum L.,

Endophytic bacterial population, Hybrid and local varieties

\section{Article Info}

Accepted:

26 January 2018

Available Online:

10 February 2018 is well studied in genetics, genomics, breeding and being an excellent model for the basic and applied research related to fruit quality, stress tolerance and other physiologic traits. In the present study, a microbial aspect of tomato, in terms of the endophytic bacterial population present in the plant had been studied. For the isolation of endophytic bacteria, six hybrid varieties (Kashi Sharad, Kashi Anupam, Kashi Amrit, DVRT-2, Prestige and S22 ), and two local varieties (S-3619 and Kajla) of tomato were grown in pots under natural conditions. The population dynamics of culturable endophytic bacteria in seedlings root (after 21 days) were enumerated. The endophytic population varies in all the varieties of tomato in between range from $2.8 \times 10^{3}$ to $3.5 \times 10^{5}$ (cfu) bacteria per gram of fresh root. The maximum population was observed in local variety, S-3619 $\left(3.4 \pm 0.64 X 10^{5}\right)$, whereas minimum in the variety of Kajla $\left(3.2 \pm 0.09 \times 10^{5}\right)$. In case of hybrid variety S-22 supported maximum population $3.5 \pm 0.88 \times 10^{5}$ followed by Kashi Anupam (3.3 $\left.\pm 0.08 X 103\right)$, Prestige $\left(3.1 \pm 0.0 .8 \mathrm{X} 10^{4}\right)$, DVRT-2 $\left(2.9 \pm 0.02 \mathrm{X} 10^{3}\right)$, Kashi Amrit $\left(2.1 \pm 0.06 \mathrm{X} \mathrm{10} 0^{4}\right)$ and Kashi Sharad $\left(2.4 \pm 0.08 \times 10^{3}\right)$.

\section{Introduction}

Endophytes are the microbes, which reside inside the plants without causing any harm. They colonize the internal plant tissues and form a different range of interaction including symbiotic and trophobiotic. Such bacteria promote plant growth and also act as biocontrol agents. In some cases endophytes also applied as biological agents like nanoparticles in controlling human diseases including cancer (Ryan et al., 2008; Beiranvand et al., 2017). The endophytic niche protects from the environmental stresses to those bacteria that colonize and establish in the plant. Although root is the most obvious site of entry for many endophytes, they may also occur through aerial plant parts. The diversity of endophytic microorganisms in the host plants includes both gram-positive and gram-negative which from various genera of $\alpha-, \beta-$, and $\gamma-$ proteobacteria, Actinobacteria, Firmicutes and bacteroidetes. Their presence within the plant can be detected by cultural or molecular methods (Rosenblueth and Martínez-Romero, 2006). The endophytic population is affected 
by climate change and habitat where the host plant grows. They produce a wide range of compounds useful for plant growth, protection from environmental stresses, and sustainability. They protect plants from herbivory by producing certain chemicals which prevent animals from grazing and sometimes act as bio-control agents (Nair and Padmavathy, 2014). Endophytic bacteria are being used successfully in a number of developing countries to reduce the number of agrochemicals which is becoming a leading cause of pollution now a day. The enhancement of bacterial colonization spurred by specific $\mathrm{C}$ and $\mathrm{N}$ exudates by plant root cap and border cells and the capacity of certain bacteria to modulate plant metabolism which could provide insight into the mutualistic plant-endophyte relationships (Himani et al., 2016).

Since last two decades, the interest in endophytic bacteria has arisen due to the discovery of numerous possible applications. Being a relatively new field, endophyte produces a large reservoir of bioactive compounds (Singh et al., 2017b). These bioactive compounds like alkaloids, terpenoids, phenols find applications in various fields due to their significant properties like production of antimicrobials, antibiotics and anticancer drugs. Endophytic bacteria and their secondary metabolites find its use in agriculture as biological agents, plant growth regulator, biotic elicitor and biofertilizer (Ryan et al., 2008; Compant et al., 2013). They promote plant growth by several mechanisms such as phosphorus solubilization, nitrogen fixation, nutrient uptake, maintenance of soil fertility, production of volatile organic compounds, induction of systemic disease resistance and resistance of water stress (Malusa et al., 2016).

Tomato is the second most widely consumed vegetable crop and it is an important source of bioactive compounds like lycopene, phenolics, vitamins and ascorbic acid, essential amino acids and dietary fibers. It is widely grown vegetable in the world and find most common place in the kitchen garden (Rana, 2008; Singh et al., 2014; Singh et al., 2017a). The structure and function of endophytic microbial population plant-microbe interactors are important for understanding the plant-microbe interactions and their ecological role (Hardoim et al., 2008). The results of such study can be used to assess the fate of released strains and their impact on resident microbial communities (Procopio et al., 2009). In the present study culturable endophytic bacteria population were enumerated from local and hybrid varieties of tomato plant parts, and plants surviving at high (upto $46-47^{0} \mathrm{C}$ ) temperature using selective media.

\section{Materials and Methods}

\section{Pot experiment}

Tomato seeds of six hybrid varieties (Kashi Sharad, Kashi Anupam, Kashi Amrit, DVRT2, Prestige and S-22), and two local varieties, (S-3619 and Kajla) were collected from vegetable section of Indian Institute of Vegetable Research, Varanasi (India) and local market of Varanasi. The seeds were washed with double distilled water and sown in earthen pots containing mixture of soil, sand and compost (2:1:1), for good aeration and better growth of plants. Seed grown in earthen pots were maintained at the Botanical garden of Banaras Hindu University, campus under natural conditions.

\section{Isolation of endophytic bacterial strain}

Explants (root, stem and leaves) were used as experimental material to determine the culturable population of endophytic bacteria. Explants were collected from different varieties of tomato plants, thoroughly washed in running tap water and surface sterilized (70 
$\% \mathrm{C}_{2} \mathrm{H}_{5} \mathrm{OH}, 3 \mathrm{~min}, 0.5 \% \mathrm{NaOCl}, 3 \mathrm{~min}$ and $\left.70 \% \quad \mathrm{C}_{2} \mathrm{H}_{5} \mathrm{OH}, 30 \mathrm{~s}\right)$. Finally, they were washed thrice with sterile distilled water (Sun et al., 2008).

The explants were air dried, cut into small pieces nearly $0.25 \mathrm{~cm}$ length with the help of sterilized razor blade or crushed aseptically before placing on Luria nutrient, King's B, Jensen's, Nitrate minimal salt (King et al., 1954; Prajapati et al., 2017, Jensen, 1940) agar media plates and incubated in the bacteriological incubator at $38 \pm 1^{\circ} \mathrm{C}$ for $2-7$ days for colonies growth around the cut sections and on crushed plant samples till the pin head colonies or visible growth appeared.

Colonies were isolated and pure clones of endophytic bacteria were screened by restreaking on their respective media. The isolates were maintained on slants and stored at $4^{0} \mathrm{C}$ for further studies (Kumar et al., 2016)

\section{Enumeration of endophytic bacterial population}

The standard plate count (SPC) method was employed to determine the culturable population of endophytic bacteria in the different explants of the plant. The homogenized solution (1ml) of each surface sterilized explants were inoculated on Luria nutrient agar medium for the total count of the bacteria, and Jensen's agar media for the nitrogen fixing bacteria, Kings's B for the Pseudomonas sp. and NMS (Nitrate mineral salts) agar medium for Methylotrophic bacteria. Petridishes were incubated on $38 \pm 1^{0} \mathrm{C}$ in the bacteriological incubator till the visible colonies appeared on the plates. Colonies were counted in a colony counter. Three replicates were used for each subset. Similar isolation procedure had been followed for enumeration of the endophytic bacterial population from the plants tolerating $46-47^{\circ} \mathrm{C}$.

\section{Statistical analysis}

The data were analyzed for analysis of variance (ANOVA). Mean \pm standard deviation was determined using SPSS version 16.0. Sigma plot was used for histograms. Population dynamics were estimated by using CFU (LN value) subjected to logarithmic transformation before data analysis.

\section{Results and Discussion}

\section{Seed germination in different varieties of} Lycopersicum esculentum $\mathrm{L}$.

The 100 seeds of each variety of tomato were sown at $1 \mathrm{~cm}$ depth in the earthen pots with sufficient moisture content. The percent of germination was observed on the seventh day from the day of sowing. The maximum percentage of seed germination $88 \pm 4 \%$ was observed in S-22 (hybrid) among the all hybrid varieties while lowest seed germination $36 \pm 5 \%$ was recorded in Kajla (Local) (Table $1)$.

Population dynamics of endophytic bacteria were determined in eight different varieties of tomato (six hybrids and two local), seedlings root of 21 days old and the results have been presented in Table 1. The maximum bacterial count in local variety $S-3619$ was $3.4 \pm 0.64 X$ $10^{5}$ while the hybrid variety $\mathrm{S}-22$ supported the population size of $3.5 \pm 0.88 \times 10^{5}$. Since both the varieties supported maximum number of endophytic bacteria, they were taken for further investigations (Table 1).

Population of endophytic bacteria from the roots of local (S-3619) and hybrid (S-22) varieties in different growth media

The population of endophytic bacteria in different plant parts of hybrid (S-22) and local variety (S-3619) of tomato were determined in four selective growth media in order to know 
the counts of total bacteria including Pseudomonas, $\mathrm{N}_{2}$-fixing and Methylotrophic bacteria. Local varieties explants root, stem and leaf of local variety supported a greater number of endophytic bacteria on four different nutrient media compared to hybrid variety. The local variety plant parts supported more population on Luria nutrient agar medium followed by King's B, Jensen's and Nitrate mineral salt media. The local variety root supported more population $3.4 \pm 0.64 \times 10^{5}$ followed by stem $2.8 . \pm 0.09 \times 10^{5}$ and leaf $2.6 \pm 0.06 \times 10^{4}$, while the least population was found in leaf on NMS medium. The order of bacterial population of local variety on selective media as follows: Luria nutrient agar $>$ King's B $>$ Jenson's $>$ NMS medium. The order of plant parts supported bacterial population was as follows: root> stem> leaf.

The hybrid variety tomato plant supported more bacterial population $3.5 \pm 0.16 \times 10^{5}$ in root explants on Luria nutrient agar medium followed by King's B $\left(3.7 \pm 0.8 X \quad 10^{4}\right)$, Jensen's $\left(2.5 \pm 0.05 \times 10^{4}\right)$ and NMS $\left(2.6 \pm 0.06 \times 10^{3}\right)$ medium, while the least population $\left(4.1 \pm 0.08 \times 10^{2}\right)$ was found in leaf on NMS medium. The order of plant parts supported bacterial population was as follows: root> stem> leaf for three selective medium Luria nutrient agar, King's B and NMS except Jenson's medium which supported more bacterial population in root and leaf followed by stem (Fig. 3).

\section{Bacterial counts in plant roots tolerating $45^{\circ} \mathrm{C}$ temperature}

Endophytic bacteria counts were enumerated in the plant roots tolerating $46-47^{\circ} \mathrm{C}$ temperature. The data revealed that the total culturable bacterial count on Luria nutrient agar plate was $1.3 \pm 0.07 \times 10^{3}$. The population of Pseudomonas was higher than the $\mathrm{N}_{2}$ fixing bacteria while Methylotrophs were present in minimal number (Table 2) and Figure 4.
Population dynamics of culturable endophytic bacteria in different plant parts at different growth stages

Population dynamics of endophytic bacterial strains were recorded after $7,15,30,45,60$, and 90 days of sowing from different plant parts including root, stem, leaf and flower on the Luria nutrient agar medium. The data revealed that maximum number (CFU) of endophytic bacteria was present in the root $3.6 \pm 0.05 \times 10^{5}$ after 45 days of sowing, whereas lowest populations $1.3 \pm 0.08 \times 10^{3}$ was recorded after 90 days of sowing. In the stem of tomato plant maximum number of endophytic bacteria $5.0 \pm 0.11 \times 10^{4}$ were observed after 45 days of sowing, whereas lowest population $1.2 \pm 0.07 \quad \times 10^{3}$ was recorded at 90 day on nutrient agar medium. The maximum number of bacteria leaf $\left(3.6 \pm 0.07 \times 10^{4}\right)$ was found on $30^{\text {th }}$ days, while lowest $\left(1.1 \pm 0.07 \times 10^{2}\right)$ number was observed after 90 days of sowing. Bacterial enumeration in flower was recorded on only two days 60 (initial flowering) and 90 days (last stage of flowering) after sowing, and population was $2.6 \pm 0.09 \times 10^{4}$ and $3.7 \pm 0.12 \quad \times 10^{4}$, respectively. The order of endophytic bacteria in different plant parts described as root> stem $>$ flower $>$ leaf (Table 3 ).

Endophytic bacteria are important constituents of the plant micro-environment system, providing important services that promote plant growth and disease prevention (Forchetti et al., 2010). Bacterial endophytes are nonpathogenic bacteria that also contribute to the plants ability to adapt to adverse conditions (Shen and Fulthorpe, 2015). In the present study results on the germination of all hybrid varieties was superior to the local variety except Kashi Sharad. Hybrids varieties may be bred to be more widely adapted to environmental stresses such as heat, cold, disease or drought, since the germination was superior to local varieties. 
Fig.1 Seed germination in eight different varieties of tomato seeds

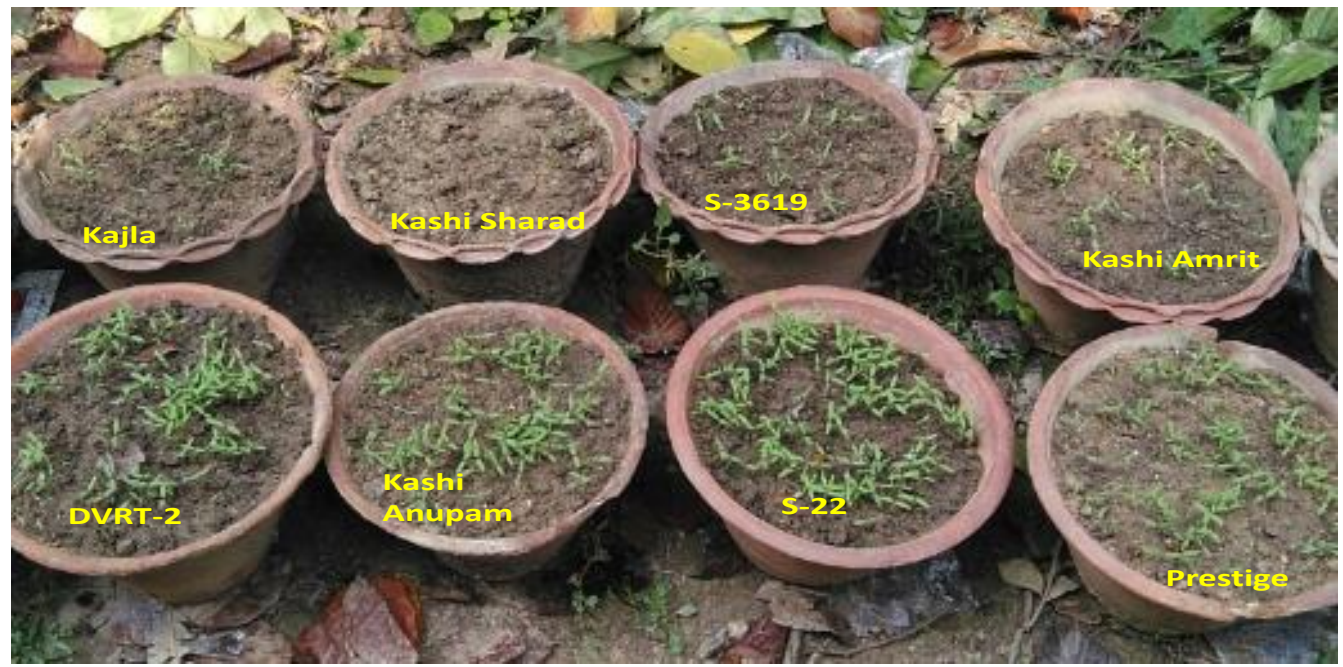

Fig.2 Colony growth of endophytic bacteria from the variety S-22 (A) root explants and (B) from crushed roots of 22 days old tomato seedlings

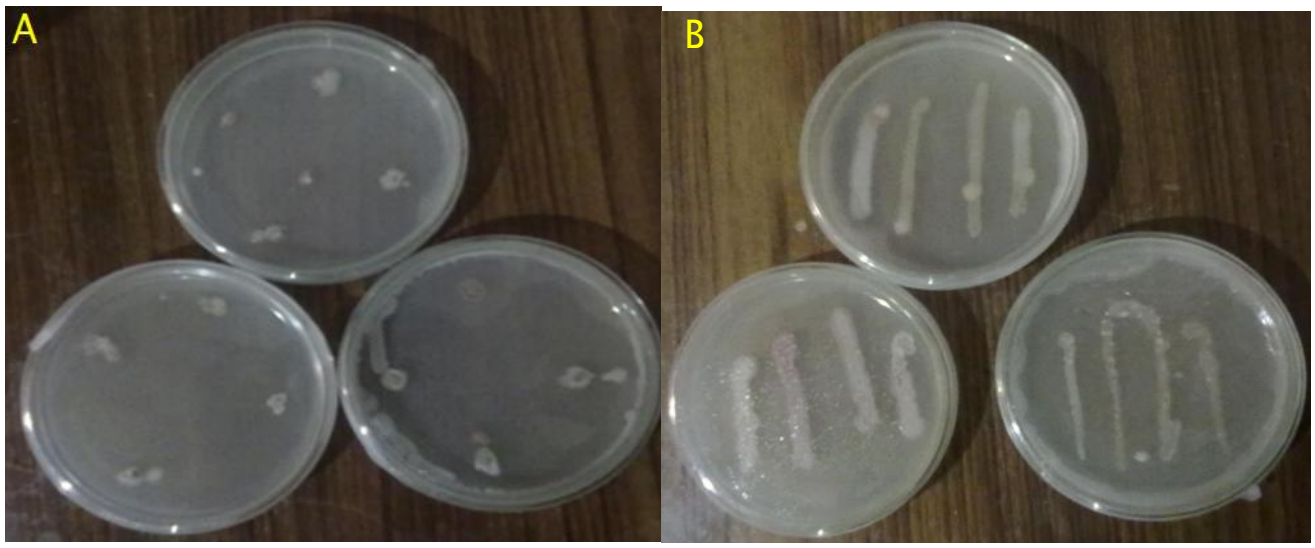

Fig.3 Population dynamics of endophytic bacteria in 21days old seedlings of hybrid (A) S-22, and (B) local (S-3619) tomato varieties on different selective media
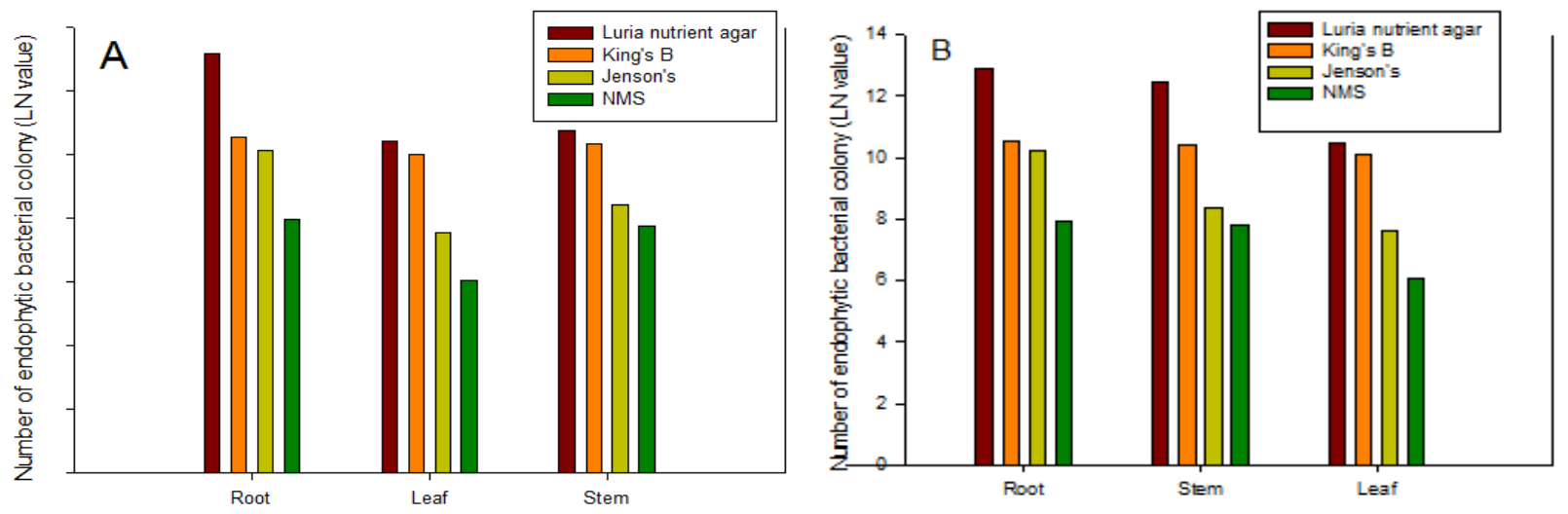
Fig.4 Total bacterial population tolerating at $45 \pm 1^{0} \mathrm{C}$ on different agar media

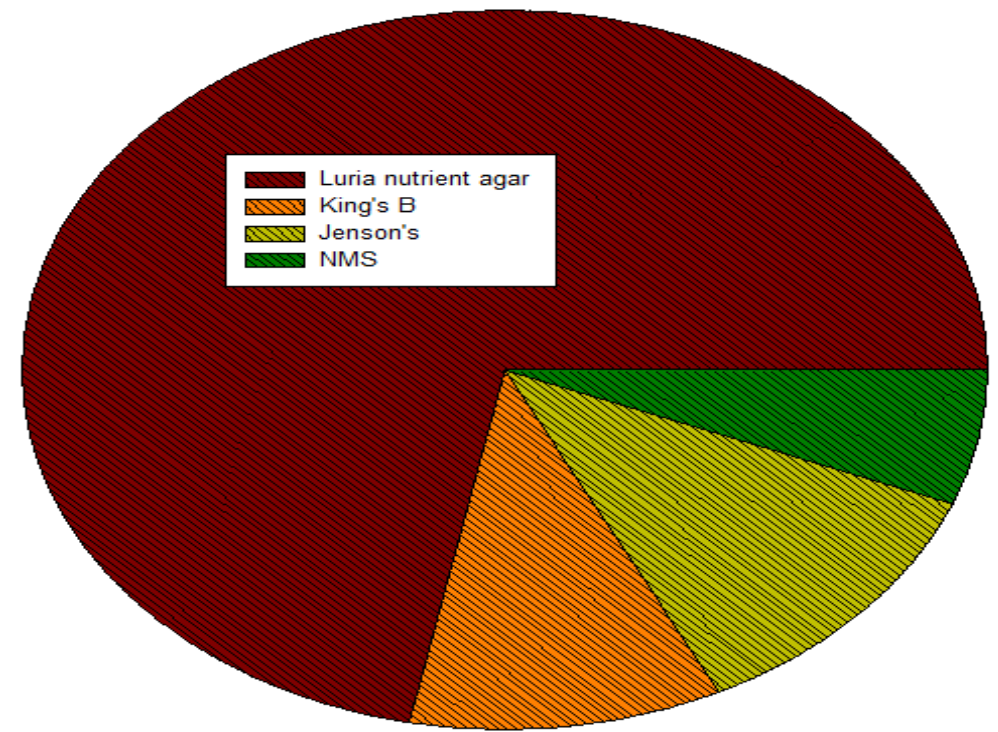

Table.1 Bacterial population and percent of seed germination in eight tomato varieties

\begin{tabular}{|l|l|l|l|l|}
\hline S. No. & Name & Variety type & $\begin{array}{l}\text { Percent of } \\
\text { germination }\end{array}$ & $\begin{array}{l}\text { Total bacterial count } \\
\text { (crushed root) on Luria } \\
\text { nutrient agar* }\end{array}$ \\
\hline 1. & Kashi Sharad & Hybrid & $28 \pm 2 \%$ & $2.4 \pm 0.08 \times 10^{3}$ \\
\hline 2. & Kashi Anupam & Hybrid & $75 \pm 6 \%$ & $3.3 \pm 0.08 \times 10^{3}$ \\
\hline 3. & DVRT-2 & Hybrid & $79 \pm 5 \%$ & $2.9 \pm 0.02 \times 10^{3}$ \\
\hline 4. & Kashi Amrit & Hybrid & $42 \pm 3 \%$ & $2.1 \pm 0.06 \times 10^{4}$ \\
\hline 5. & Prestige & Hybrid & $68 \pm 4 \%$ & $3.1 \pm 0.0 .8 \times 10^{4}$ \\
\hline 6. & Kajla & Local & $36 \pm 5 \%$ & $3.2 \pm 0.09 \times 10^{5}$ \\
\hline 7. & S-22 & Hybrid & $88 \pm 6 \%$ & $3.5 \pm 0.88 \times 10^{5}$ \\
\hline 8. & S-3619 & Local & $41 \pm 4 \%$ & $3.4 \pm 0.64 X 10^{5}$ \\
\hline
\end{tabular}

* Seedling roots of 21 days old were used for enumeration and expressed as count of $1 \mathrm{gm}$. fresh wt.

Table.2 Population of endophytic of bacteria in hybrid variety (S-22) root tolerating $45^{\circ} \mathrm{C}$ temperature

\begin{tabular}{|l|}
\hline Medium \\
\hline Luria nutrient agar \\
\hline King's B \\
\hline Jenson \\
\hline Nitrate mineral salt \\
\hline
\end{tabular}


Table.3 Enumeration of endophytic bacteria from the different plant parts during the growth cycle from the root, stem, and leaf of hybrid variety (S-22)

\begin{tabular}{|l|l|l|l|l|}
\hline $\begin{array}{l}\text { No. of days } \\
\text { after sowing }\end{array}$ & Root & Stem & Flower & Leaf \\
\hline 7 & $2.5 \pm 0.08 \times 10^{3}$ & $1.6 \pm 0.07 \times 10^{3}$ & 0 & $1.2 \pm 0.07 \times 10^{3}$ \\
\hline 15 & $3.4 \pm 0.09 \times 10^{3}$ & $2.4 \pm 0.07 \times 10^{3}$ & 0 & $1.9 \pm 0.07 \times 10^{4}$ \\
\hline 21 & $3.6 \pm 0.08 \times 10^{4}$ & $4.6 \pm 0.08 \times 10^{4}$ & 0 & $3.2 \pm 0.06 \times 10^{4}$ \\
\hline 30 & $3.5 \pm 0.12 \times 10^{5}$ & $4.8 \pm 0.07 \times 10^{4}$ & 0 & $3.6 \pm 0.07 \times 10^{4}$ \\
\hline 45 & $3.6 \pm 0.05 \times 10^{5}$ & $5.0 \pm 0.11 \times 10^{4}$ & 0 & $3.8 \pm 0.07 \times 10^{3}$ \\
\hline 60 & $4.1 \pm 0.07 \times 10^{4}$ & $5.2 \pm 0.08 \times 10^{3}$ & $2.6 \pm 0.09 \times 10^{4}$ & $3.1 \pm 0.07 \times 10^{3}$ \\
\hline 90 & $1.3 \pm 0.07 \times 10^{3}$ & $1.2 \pm 0.09 \times 10^{3}$ & $3.7 \pm 0.12 \times 10^{4}$ & $1.1 \pm 0.07 \times 10^{2}$ \\
\hline
\end{tabular}

They often have more uniform characteristics and the local varieties are less viable than hybrid varieties (Ali, 2006). Tomato varieties supported to good growth of endophytic bacteria belonging to $a-, \beta-$ and $\gamma$ proteobacteria and Fermicutes. Although endophytic bacteria from both hybrid and local varieties resistant belonged to diversified group of Eubacteria. Bacterial community composition results from the interaction between soil type, plant species and its rhizosphere localization (Buyer et al., 2002; Vieira and Nahas, 2005). The variety of the plant contributes to the structure of the endophytic community associated with common bean plants (Costa et al., 2012).

Population dynamics of endophytic bacteria recorded from root, stem and leaf, of Lycopersicum esculentum L. from different growth phases suggested their presence in every plant parts, however, root is main organ for their colonization. Several studies have shown that endophytes are widely present in plant tissues, such as the roots, stems, leaves, and flowers (Kobayashi and Palumbo, 2000). The close proximity of soil would have contributed to the more diverse population of endophytes in the root tissues than stem and leaves tissues (Aravind et al., 2009). The roots harbored a more diverse population of endophytic bacteria than stem in Lycopersicum esculentum $\mathrm{L}$. The observations that endogenous bacterial population was higher in roots may reflect the fact that the root is the primary site of entry in the plants (Lodewyckx et al., 2002). Diverse communities of bacteria inhabiting plant leaves play a crucial role for plant growth and health (Bodenhausen et al., 2013). Endophytic bacterial populations can be regarded as a subset of the soil microbial community and are thus partially influenced by the soil's environment; however, the rhizosphere microbial communities of different plant species growing in the same soil are distinct (Marschner et al., 2004; Garbeva et al., 2008). The abiotic components of soil and also the plant development stages can affect the diversity of endophytic bacterial community and the mechanism of bacterial colonization (Hardoim, 2011).

Endophytic bacteria is an important constituent of plant-microbe interaction, and broadly used in sustainable agriculture as biocontrol, biofertilizer or stress management. Generally endophytes are non-pathogenic in nature and contribute to the plants by maintaining adverse conditions. In the present study endophytic bacterial population had been enumerated at normal or elevated temperature at $46-47^{\circ} \mathrm{C}$. The results revealed that local variety is more tolerant to hybrid vaiety in terms of bacterial population. This study may. The endophytic bacterial 
population observed in tomato plants surviving at $46-47^{\circ} \mathrm{C}$ postulates that strains help the researchers to use endophytic strains in drought management and also play significant role for tomato cultivation under climate change. However, further investigations are required to fulfill this hypothesis and its cultivation at a higher temperature.

\section{Acknowledgements}

This work was supported by DST-Inspire (to Monika Singh), University Grant Commission (CAS in Botany), DST-FIST, New Delhi, India. Authors thanks to Head, Department of Botany, Banaras Hindu University, for providing facilities

\section{References}

Ali, M., 2006. Chili (Capsicum spp.) food chain analysis: Setting research priorities in Asia. AVRDC-The World Vegetable Center. Technical Bulletin No, 38.

Aravind, R., Kumar, A., Eapen, S.J. and Ramana, K.V., 2009. Endophytic bacterial flora in root and stem tissues of black pepper (Piper nigrum L.) genotype: isolation, identification and evaluation against Phytophthora capsici. Lett Appl Microbiol, 48(1), 58-64.

Beiranvand, M., Amin, M., Hashemi-Shahraki, A., Romani, B., Yaghoubi, S. and Sadeghi, P., 2017. Antimicrobial activity of endophytic bacterial populations isolated from medical plants of Iran. Iran J Microbiol, 9(1), 11.

Bodenhausen, N., Horton, M.W. and Bergelson, J., 2013. Bacterial communities associated with the leaves and the roots of Arabidopsis thaliana. PloS One, 8(2), p.e56329.

Buyer, J.S., Roberts, D.P. and Russek-Cohen, E., 2002. Soil and plant effects on microbial community structure. Can J Microbiol, 48(11), 955-964.

Compant, S., Brader, G., Muzammil, S., Sessitsch, A., Lebrihi, A. and Mathieu, F., 2013. Use of beneficial bacteria and their secondary metabolites to control grapevine pathogen diseases. Bio Control, 58(4), 435-455.

Costa, L.E.D.O., Queiroz, M.V.D., Borges, A.C., Moraes, C.A.D. and Araujo, E.F.D., 2012. Isolation and characterization of endophytic bacteria isolated from the leaves of the common bean (Phaseolus vulgaris). Braz $\mathbf{J}$ Microbiol, 43(4), 1562-1575.

Forchetti, G., Masciarelli, O., Izaguirre, M.J., Alemano, S., Alvarez, D. and Abdala, G., 2010. Endophytic bacteria improve seedling growth of sunflower under water stress, produce salicylic acid, and inhibit growth of pathogenic fungi. Curr Microbiol, 61(6), 485-493.

Garbeva, P., Van Elsas, J.D. and Van Veen, J.A., 2008. Rhizosphere microbial community and its response to plant species and soil history. Plant and soil, 302(1-2), 19-32.

Hardoim, P.R., 2011. Bacterial endophytes of rice: their diversity, characteristics and perspectives, University of Groningen, pp. $1-220$.

Hardoim, P.R., Van Overbeek, L.S. and Van Elsas, J.D., 2008. Properties of bacterial endophytes and their proposed role in plant growth. Trends Microbiol, 16(10), 463-471.

Himani, C., Singh, V. and Gupta, G., 2016. Potential of bacterial endophytes as plant growth promoting factors. J Plant Pathol Microbiol. 7(9), 1-6.

Jensen, H. L. 1940. Contributions to the nitrogen economy of Australian wheat soils, with particular reference to New South Wales. Proc. Linn. Soc. N.S.W. 65: 1-122.

Kin g, E.O., Ward, M.K. and Raney, D.E. (1954) Two simple media for the demonstration of pyocyanin and £uorescin. J. Lab. Clin. Med. 44, 301^307

Kin g, E.O., Ward, M.K. and Raney, D.E. (1954) Two simple media for the demonstration of pyocyanin and £uorescin. J. Lab. Clin. Med. 44, 301^307

King, E.O., Ward, M.K. and Raney, D.E. 1954. Two simple media for the demonstration of pyocyanin and fuorescin. J Lab Clin Med, 44, 301-307.

Kobayashi, D.Y. and Palumbo, J.D., 2000. Bacterial endophytes and their effects on plants and uses in agriculture. Microbial endophytes, 19, 199-233. 
Kumar, A., Singh R., Yadav, A., Giri, D.D., Singh, P.K. and Pandey, K.D., 2016. Isolation and characterization of bacterial endophytes of Curcuma longa L. 3 Biotech, 6:60.

Lodewyckx, C., Vangronsveld, J., Porteous, F., Moore, E.R., Taghavi, S., Mezgeay, M. and der Lelie, D.V., 2002. Endophytic bacteria and their potential applications. Crit Rev Plant Sci, 21(6), 583-606.

Malusa, E., Pinzari, F. and Canfora, L., 2016. Efficacy of biofertilizers: challenges to improve crop production. In Microbial inoculants in sustainable agricultural productivity Springer India, 17-40.

Marschner, P., Crowley, D. and Yang, C.H., 2004. Development of specific rhizosphere bacterial communities in relation to plant species, nutrition and soil type. Plant and soil, 261(1), 199-208.

Nair, D.N. and Padmavathy, S., 2014. Impact of endophytic microorganisms on plants, environment and humans. Sci World J, pp 1-12.

Prajapati, R.R, Vyas, R.V., and Jhala Y.K., 2017. Isolation and characterization of phyllospheric methylotrophic bacteria of paddy from middle Gujarat, India. Int.J.Curr.Microbiol.App.Sci 6(5): 21862208

Procopio, R.E.L., Araújo, W.L., Maccheroni Jr, W. and Azevedo, J.L., 2009. Characterization of an endophytic bacterial community associated with Eucalyptus spp. Genetics and Molecular Research, 8(4), 1408-1422.

Rana, M.K. 2008. Olericulture in India. Kalyani Publishers, New Delhi.

Rosenblueth, M. and Martinez-Romero, E., 2006.
Bacterial endophytes and their interactions with hosts. Molecular plant-microbe interactions, 19(8), 827-837.

Ryan, R.P., Germaine, K., Franks, A., Ryan, D.J. and Dowling, D.N., 2008. Bacterial endophytes: recent developments and applications. FEMS Microbiol Lett, 278(1), 1-9.

Shen, S.Y. and Fulthorpe, R., (2015) Seasonal variation of bacterial endophytes in urban trees. Front Microbiol 6:427.

Singh M, Singh, N.P., Arya S. and Singh, B., Vaishali., 2014. Diversity analysis of tomato germplasm (Lycopersicom esculentum markers) using SSR. Int J Agri Sci Res (IJASR), 4(4), 41-48.

Singh, M., Kumar, A., Garima, C., Tiwari, S., Vandana., Maurya, S.K. and Pandey, K.D., 2017a. Influence of varying temperature on the bioactive compounds of Solanum lycopersicum. L after post-harvest storage. Int J Curr Microbiol Appl Sci, 6(6): 29973007.

Singh, M., Kumar, A., Singh, R. and Pandey, K.D., 2017b. Endophytic bacteria: a new source of bioactive compounds. 3 Biotech, 7(5), 315.

Sun, L., Qiu, F., Zhang, X., Dai, X., Dong, X. and Song, W., 2008. Endophytic bacterial diversity in rice (Oryza sativa L.) roots estimated by $16 \mathrm{~S}$ rDNA sequence analysis. Microb Ecol, 55(3), 415-424.

Vieira, F.C.S. and Nahas, E., 2005. Comparison of microbial numbers in soils by using various culture media and temperatures. Microbiol Res, 160(2), 197202.

\section{How to cite this article:}

Monika Singh, Prem Pratap Singh, Arun K. Patel, P.K. Singh and Pandey, K.D. 2018. Enumeration of Culturable Endophytic Bacterial Population of Different Lycopersicum esculentum L. Varieties. Int.J.Curr.Microbiol.App.Sci. 7(02): 3344-3352.

doi: https://doi.org/10.20546/ijcmas.2018.702.400 